\title{
ON ROAD FUEL CONSUMPTION MEASUREMENTS IN A TRUCK AT CONSTANT SPEED USING A TOWING TRAILER WITH ELECTROMAGNETIC BRAKE SIMULATING VARIED UPHILLS.
}

\author{
Haraldo Rehder ${ }^{1}$ and Gustavo P. Rehder ${ }^{2}$
}

\author{
Rehder Consultoria de Engenharia ${ }^{1}$, \\ Laboratory of Microelectronics - University of São Paulo² \\ rehder.consult@gmail.com¹ ${ }^{1}$ grehder@lme.usp.br²
}

\section{ABSTRACT}

Global warming is the subject of national and international policies and legislation. The importance of on road testing in commercial vehicles, under real conditions of application is therefore increasing. For the execution of the Diesel consumption tests under real conditions and reproducible, it is used a heavy truck and a towing trailer prototype with electromagnetic brake, object of several presentations and papers, including SIMEA 2015. Concerning this Prototype, Patent was required to INPI, a support by FAPESP got through a PIPE Project and an approval by the competent authorities for running on road was granted.

Fuel consumption tests were performed on plain road by constant speed of $20 \mathrm{~km} / \mathrm{h}$ and different electromagnetic braking torques, simulating different road uphill. The procedure repeated several times checks the reproducibility of the methodology. With the change of parameters and components of the tractor truck, the influence of these factors on consumption can be evaluated. Future tests on the road under real application will be performed and the values obtained in that tests at constant speed will serve as a parameter for the evaluation of the consumption on road conditions. This methodology can be used, in the future, in emission evaluation.

\section{INTRODUCTION}

Global warming is a subject of national and international policies and legislation [1], [2], [3], the Air Pollution especially in big cities is of real concern worldwide [4]. In Brazil, the emission legislation for Diesel was developed by PROCONVE and at present defines the emission limits according to CONAMA FASE 7, similar to Euro 5 in Europe [5]. The importance of energy savings 
is raising in all sectors; for example, passenger's cars, see PROGRAMA BRASILEIRO DE ETIQUETAGEM PBE [6]. The Brazilian Labelling Program (PBEV), was promoted and regulated by INMETRO by the Decree (Portaria) 544/12 [7] and supported in partnership with CONPET [8]. For light vehicles, the Labelling Program was implemented and Borges [9] reminders that a Labelling Program allows useful information to consumers about the performance, concerning to energy efficiency, fuel consumption and the emission of gaseous pollutants and greenhouse effect. Classification of fuel consumption for heavy vehicles was not implemented [10].

In Brazil, the government defined a new Program Rota 2030 [11], that will replace the InovarAuto [12] which will focus on the energetic efficiency of passenger cars. We can assume that for commercial vehicles, due to their importance, similar programs and legislations will also follow. Emissions and fuel consumption reduction are therefore both important objectives of the automotive industries, as pointed out by many authors, for example [13] and [14].

The importance of on road emission testing under real conditions of application is increasing. For on road testing of heavy trucks, it was developed by the authors a towing trailer prototype with electromagnetic brake, see Folder [15] and Attachment 1, object of several presentations and papers [16] and [17], including SIMEA 2015 [18] and Congresso SAE Brasil 2015 [19]. Concerning this Prototype, Patent was required to INPI [20], a financial support by FAPESP got through a PIPE Project [21] and an approval by the competent authorities for running on public roads was granted [22]. It is proposed with this towing trailer, to perform fuel consumption and in future, emission tests of heavy commercial vehicles.

There are several methods for fuel consumption measurements:

- Measuring the fuel volume in the tank, for example by ultrasound or capacitive sensors [23].

- Measuring the consumed fuel mass, for instance, in paper presented at SIMEA 2015 [24 ], that evaluates the influence of tires on fuel consumption. In that case, it was used a very precise analytical scale that weights an independent fuel tank, not connected with the vehicle tank.

- Measuring the fuel consumption through CAN data of the Diesel engine [25].

- Measuring the fuel flow to the engine and the fuel return to the tank [26]

The Standard SAE J1321 201202 [27], revised on 20-12-06 defines a methodology for fuel consumption tests of trucks and buses over $10,000 \mathrm{lb}$ on testing tracks and on roads. On road tests are offered as an alternative to lower costs compared to testing tracks, but with less accuracy due to the variable environmental (traffic) conditions. According to that Standard, evaluations the tests must be carried out under controlled conditions and with an extensive data collection and constraint analysis.

\section{TOWING TRAILER}

\subsection{Development of the Prototype}

There are no stationary installations with chassis dynamometers for testing heavy vehicles in Brazil, such as that one in Mahle [28], formerly Behr, in Germany, and some few others in the world. Due to that, the authors developed a Towing Trailer Prototype with electromagnetic brake for testing on road (roads and track's testing) heavy commercial vehicles, presented in the 
Folder [15], see also Appendix 1, with the history and features of the Towing Trailer. Optimizations were introduced and the external structure view also enhanced. Fig. 1 and 2 show the new aluminum plated side walls, doors and windows were also introduced.

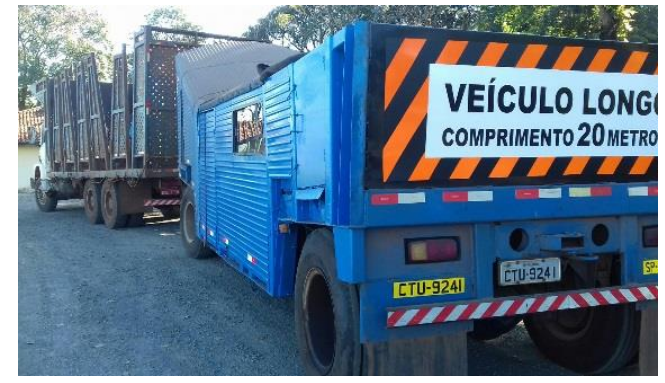

Fig. 1: Left side view with $6 \times 4$ heavy truck

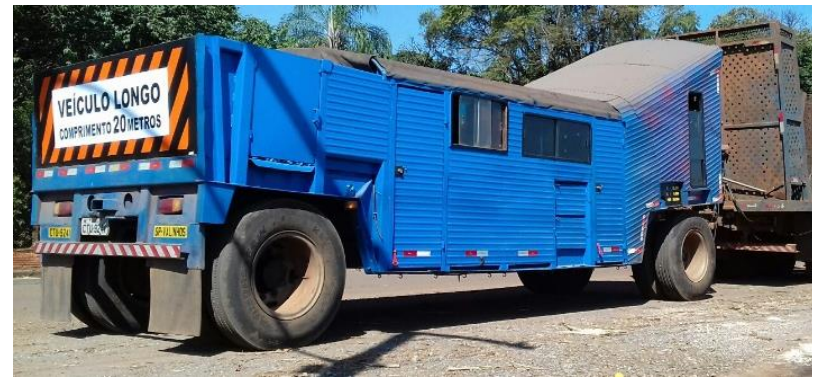

Fig. 2: Right side view with $6 \times 4$ heavy truck

The forces between truck and towing trailer are measured by strain gauge sensor, measurement of the electromagnetic braking torque was introduced based on strain gauges' sensor. The Towing Trailer Prototype was enhanced in its controls and optimized in the continuous setting of the electric current of the electromagnetic braking. The braking current is still controlled and regulated by wire in the cab. Fig. 3 and 4 shows the interior of the Prototype.

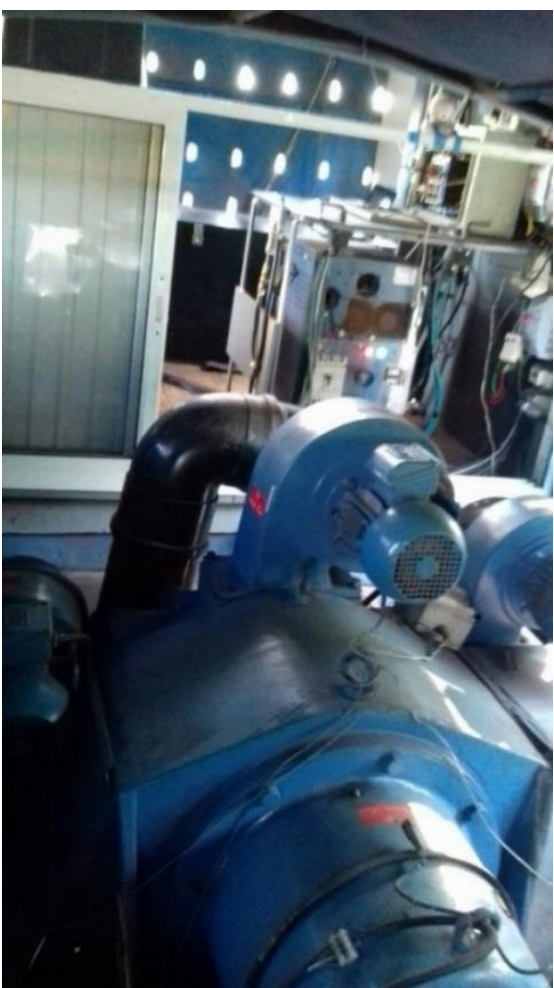

Fig. 3: Interior of the Prototype with electromagnetic brake and electro/ electronic cabin in the background.

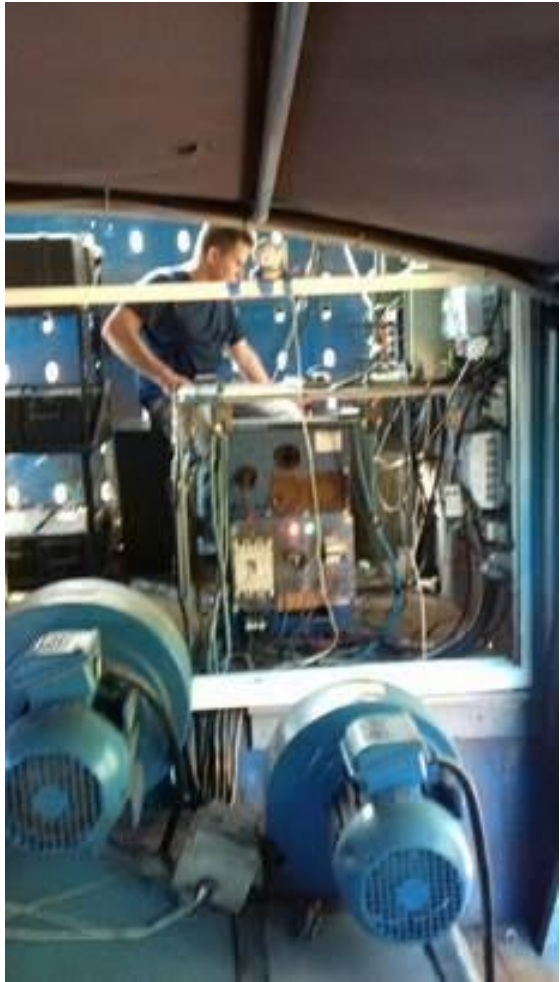

Fig. 4: Brake cooling fan and in the background, the electro/electronic cabin with operator (only standstill

\subsection{Electronic measuring systems}

The control and functional data of the Towing Trailer so as all the measured data are sent Wi-Fi to a laptop in the truck cabin. Fig. 5 shows the laptop in the interior of the truck cab and Fig. 6 
the laptop screen during a test. The vehicles speed, the time and the geographic location (latitude and longitude) is captured by a GPS and sent to the lap-top.

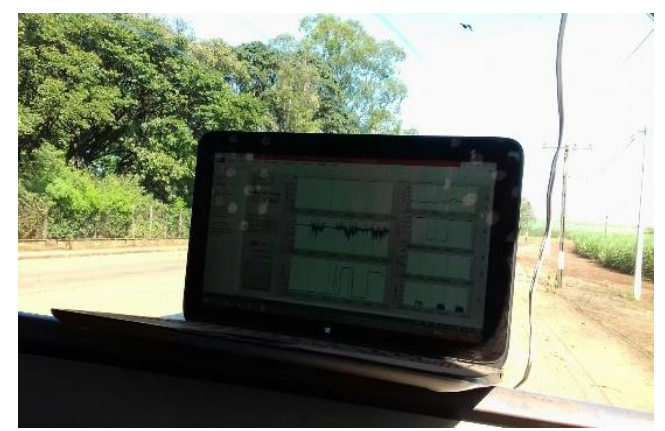

Fig. 5: Laptop inside the Truck Cab during an on-road test.

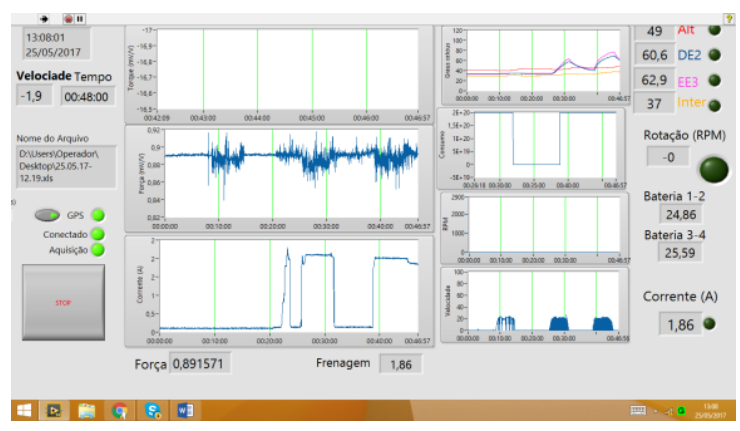

Fig. 6: Laptop screen showing measured present values and diagrams of measured data during the test.

All those data are stored in the lap-top, example of a data sheet is presented in Appendix 2.

\section{MEASUREMENT OF THE TRUCK FUEL CONSUMPTION WITH AN AUXILIARY TANK}

\subsection{Auxiliary fuel tank}

For measuring fuel consumption on road or on testing tracks, it was developed a device shown in Fig. 7 and 8 that allows initially to measure visually the fuel level (column of fuel). Capacitive fuel level measurements are ongoing and will be presented in future.

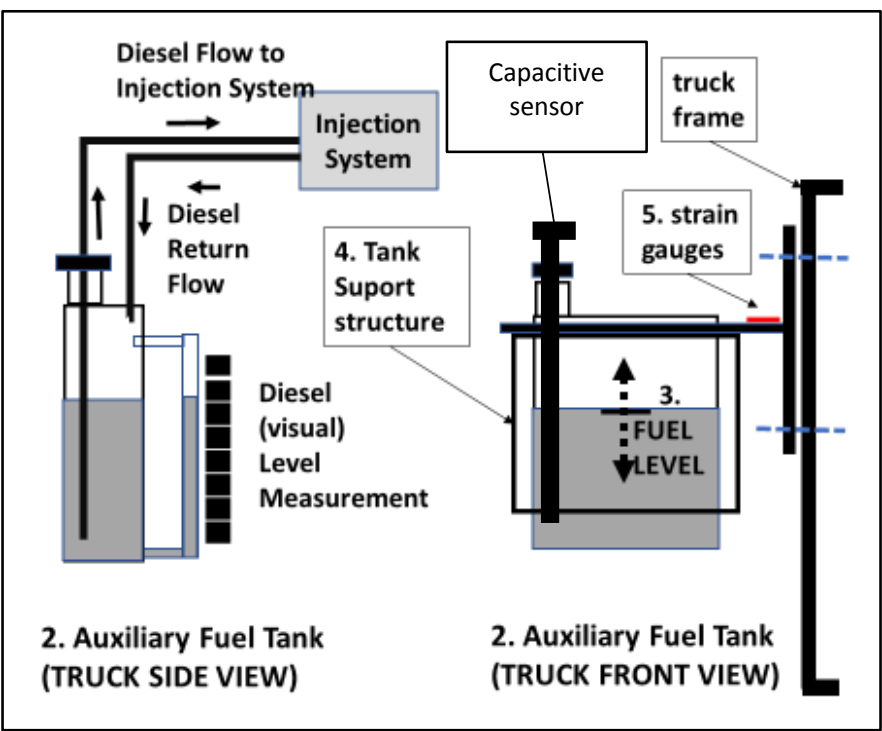

Fig. 7: Schematic views of auxiliary tank for short distances fuel measurements.

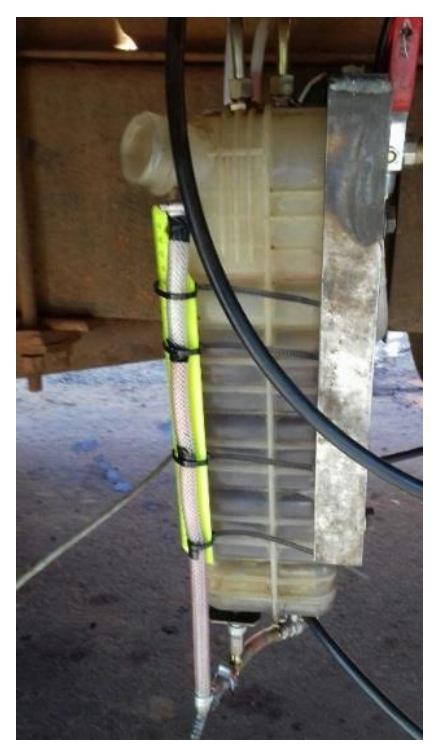

Fig. 8: Photo: auxiliary tank prototype,

fixed on truck frame

The system consists of a plastic reservoir with circa 8 liters, positioned at the level of the truck fuel tank (s) and fixed to a steel sheet structure, which is fixed on the truck chassis.

For short distances, the fuel level and the consumption can be measured by the fuel volume variation consumed in the auxiliary tank, which is not connected hydraulically to the truck fuel 
tank(s). By filling the auxiliary tank, it's possible calibrate the auxiliary tank volume as a function of the level of the fuel column.

4.2. Calibration of the fuel mass in the auxiliary tank

The proposed system also intends to measure the fuel consumption through measurement of weight (mass) of the consumed fuel. The steel structure with the auxiliary tank is suspended laterally by a steel plate that is also set in a profile $U$ and screwed in the truck frame. Strain gauge bridge was glued on this steel plate and weights the structure and the fuel mass by measuring the bending stress. Test with this system will be shown in next Chapel.

4.3. Measurement of the truck fuel volume

For consumption evaluation in longer distances, the system above explained can also be used, with the auxiliary tank connected hydraulically to the main tank(s). Due to the principle of communicating vessels, the auxiliary tank fuel level will be the same of the truck fuel tanks, if the truck is in a horizontal plane. The height of the fuel column gives an indication of the total fuel truck volume. By fulfilling the fuel tank (s) gradually, the truck fuel volume can be calibrated.

4.4. Fuel consumption measurements at $20 \mathrm{~km} / \mathrm{h}$ For performing Diesel consumption tests under real and reproducible conditions, it was used a heavy truck $6 \times 4$ with the Towing Trailer Prototype with electromagnetic brake. The weight of the truck was $13.830 \mathrm{~kg}$, and the one of the Trailer was 14.080, the total weight of those vehicles was $29.910 \mathrm{~kg}$.

Similar to the cooling tests described by the authors in $[17,18]$, fuel consumption tests with a $6 \times 4$ heavy truck and the Towing Trailer Prototype were performed at constant speed of $20 \mathrm{~km} / \mathrm{h}$ and several electromagnetic braking levels. The testing lap length was 1,7 km and the test time of each lap was almost the same. The road was plane with a roundabout in each extremity. Considering the testing costs, it was defined short test distances for each test, the purpose was to evaluate the methodology used and the sensitivity of the consumption measurements. This fuel consumption measurements use the auxiliary tank of circa 8 liters and is hydraulically independent of the main (s) truck fuel tank (s). For longer distances, the auxiliary fuel tank volume should be bigger. For measurements till $80 \mathrm{~km}$, similar to Standard SAE J1321, should be with auxiliary tank hydraulically integrated to the main truck tank and will be presented in future, in other paper.

The test laps were initially repeated 3 times without electromagnetic braking current, to evaluate the repeatability of the consumption data. The laps were then repeated with 2 and 5,0 A each, as shown in Table 1.

The average consumption of the 3 LAPS without electromagnetic braking was set a value of $100 \%$. The consumption values for 2 and 5,5 Amperes presented an increasing of respectively 39 and $140 \%$. Without current, the engine runs at partial load, with elevated currents, the engine runs near the top limit. 
Table 1: Results of the on-road fuel consumption measurements, speed $20 \mathrm{~km} / \mathrm{h}, 1,7 \mathrm{~km}$ each lap, brake currents of 0,2 and $5,5 \mathrm{~A}$.

\begin{tabular}{|c|c|c|c|c|}
\hline LAPS & LA1 to LAP3 & LAP4 & LAP5 & Remarks \\
\hline Brake current & $0 \mathrm{~A}$ & 2 A & $5,5 \mathrm{~A}$ & \\
\hline TEST Time [min] & 6 & 6 & 6 & \\
\hline LAP & LAP1 & LAP4 & LAP5 & $\begin{array}{c}\text { Each LAP }=1,7 \\
\mathrm{~km} .\end{array}$ \\
Consumption [cm] & 4,4 & 5,8 & 10 & $1 \mathrm{I}=4,5 \mathrm{~cm}$ \\
Consumption [liters] & 0,978 & 1,289 & 2,22 & LAP2 \\
\hline LAP & LAP2 & & & Repetition of \\
CAP1
\end{tabular}

\section{ELECTRONIC MEASUREMENTS}

\subsection{Laptop screen}

The laptop screen in Fig. 9 shows the measurements of 25.05.2017, consisting in the present data of time, testing time, temperatures, traction forces, braking and current level, batteries voltages. Diagrams of temperatures, traction forces and speed along the whole test are shown.

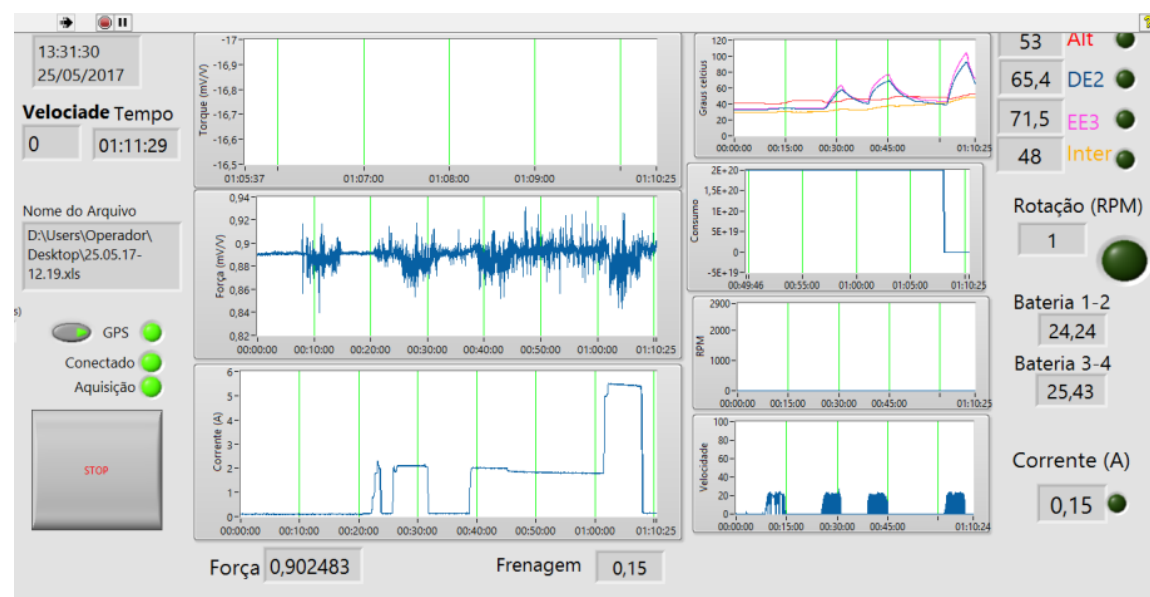

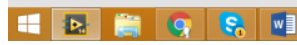

Fig. 9: Laptop screen showing measured present values and diagrams of measured data during the test on 25.05.2017.

The electromagnetic braking torque as well the fuel consumption is not indicated in the diagrams and will be discussed in next chapter.

\subsection{Worksheets}

The measured data can be assessed in the worksheets, for example (extract) in Appendix 2 and be transformed in diagrams as shown in Fig. 10 to 19. In Appendix 2, an extract of the laptop desktop shows momentanes measured data and other curves during the testing time: 
- Present values of hour, date, vehicles speed received from the GPS.

- Curves of temperatures, batteries voltage, rotation and current from electromagnetic brake system.

- Curves of traction forces, braking torque and fuel level on the auxiliary tank gotten through the developed strain gauges' sensors.

During de tests the Electromagnetic Brake (EMB) control data was measured and registered like the example shown in Figures 7 to 12, for on road test performed on 26.05.2017 from 18:57:33 to $19: 29: 45$ PM [GNT].

EMB Rotation (Fig 8), Temperatures (Fig. 10) and Batteries Voltage (Fig. 11) are used to control the function of the EMB system. The curves indicate the relationship between the EMB current (9) and the EMB torque (10) and the possibility to measure those variables

A former static calibration of the torque performed with a manual lift and an analogic dynamometer indicated a value of $0,210 \mathrm{mV} / \mathrm{V}$ for a force of $5000 \mathrm{~N}$ and a lever of $0,2 \mathrm{~m}$, resulting in a torque of $1.000 \mathrm{Nm}$. The EMB torque by a current of 5,0 A corresponds to 4,88 $\mathrm{mV} / \mathrm{V}$.

\subsection{GPS measurements}

The GPS in the truck cab roof sends the data to the laptop. The present time, testing time and speed are indicated on the laptop screen. The speed during the whole test is shown in a curve. The latitude and the longitude from worksheet as well the speed can be transformed in curves as shown in Fig. 10, 11 and 12. Fig. 13 present the test route obtained from latitude and longitude. In Fig. 12 the lap of $1.7 \mathrm{~km}$ with the two roundabouts, can be seen.

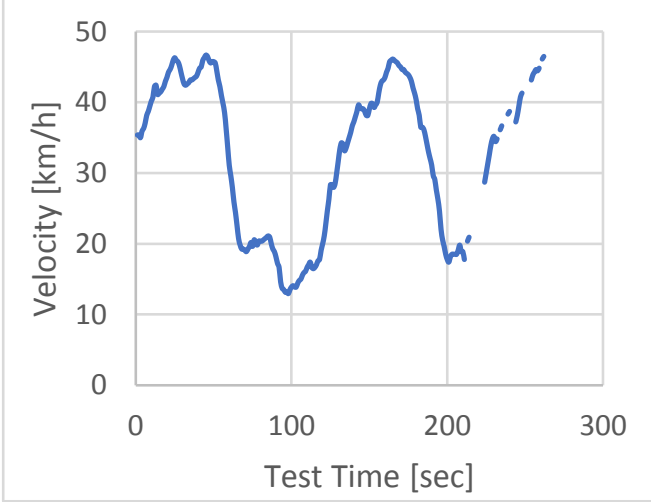

Fig. 10: Test on 30.03.2017. Speed max. 48 $\mathrm{km} / \mathrm{h}$.

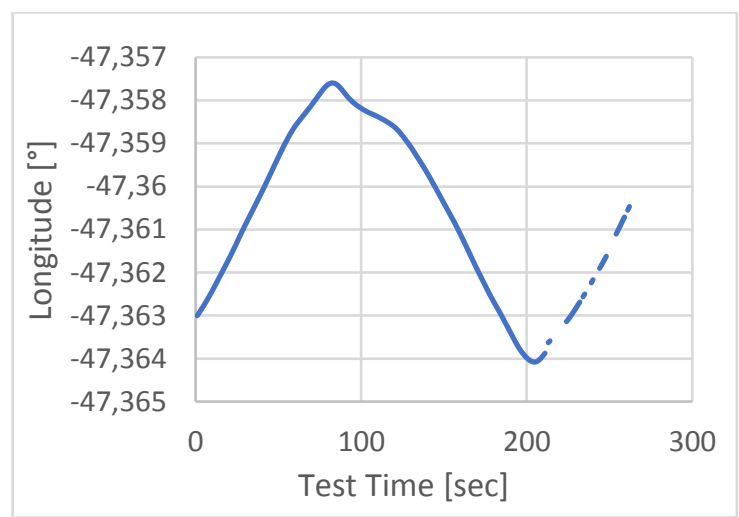

Fig. 11: Test on 30.03.2017. Longitude 


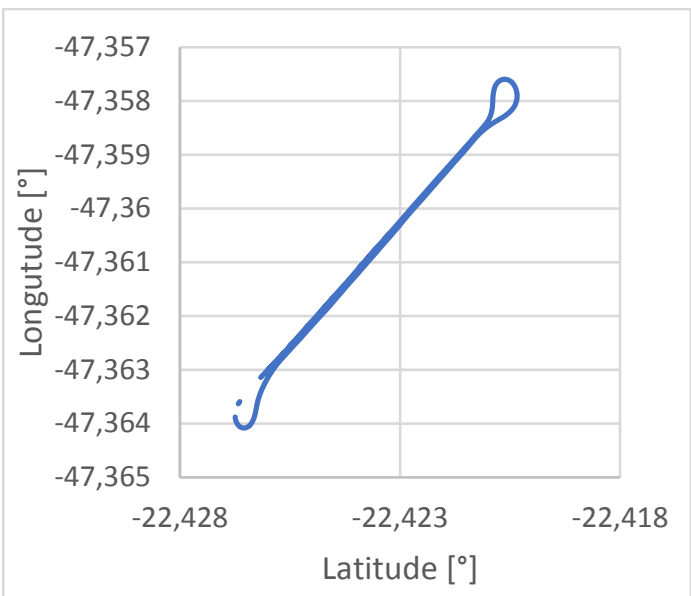

Fig. 12: Testing route.

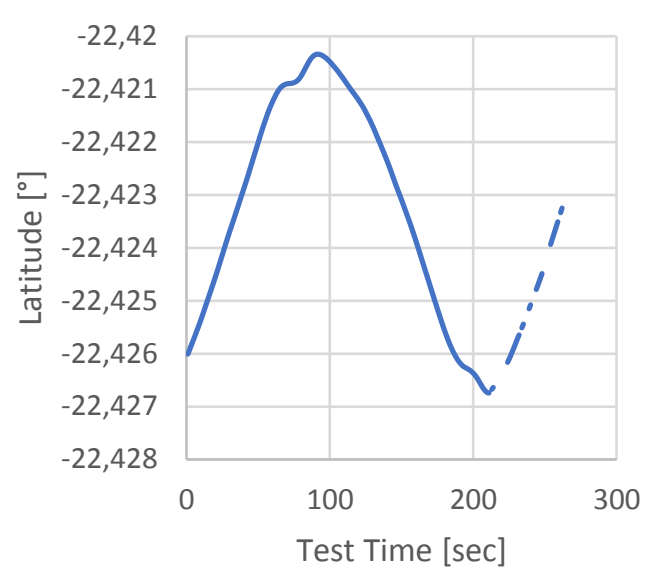

Fig. 13: Test on 30.03.2017. Longitude

5.4. Electromagnetic brake control data

From the worksheet is possible to get curves of the control data of the function of the electromagnetic brake, like in Fig. 14 to Fig. 17.

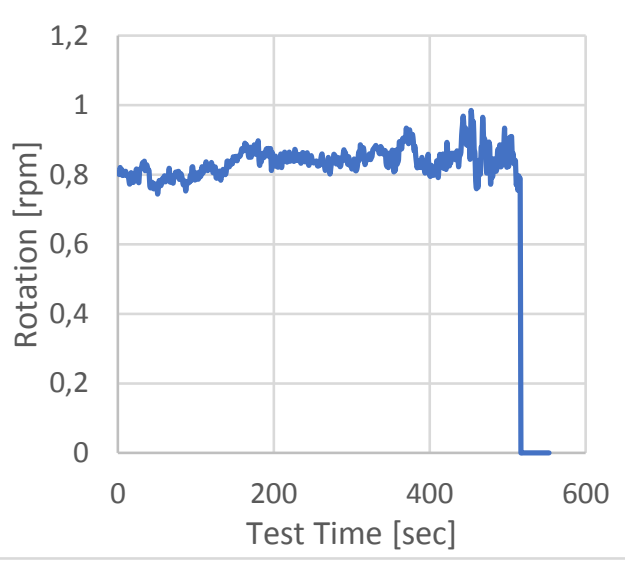

Fig. 14: Rotation

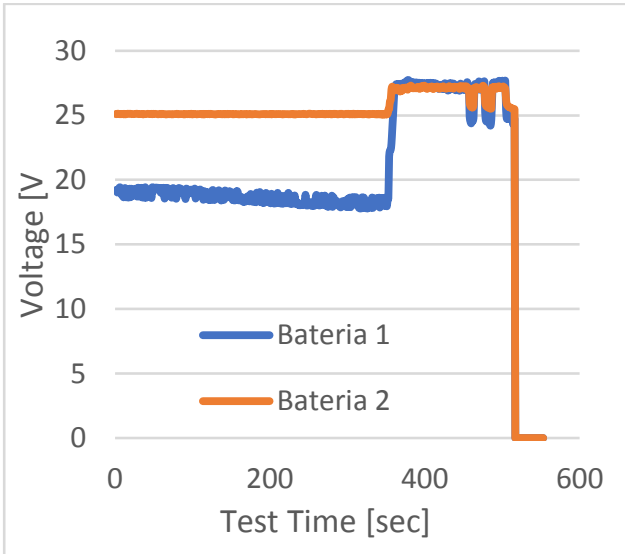

Fig. 16: Battery Voltage

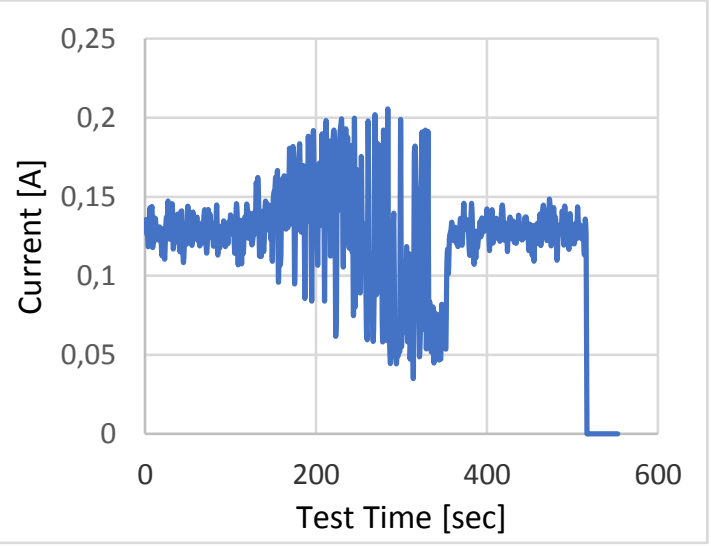

Fig. 15: Current

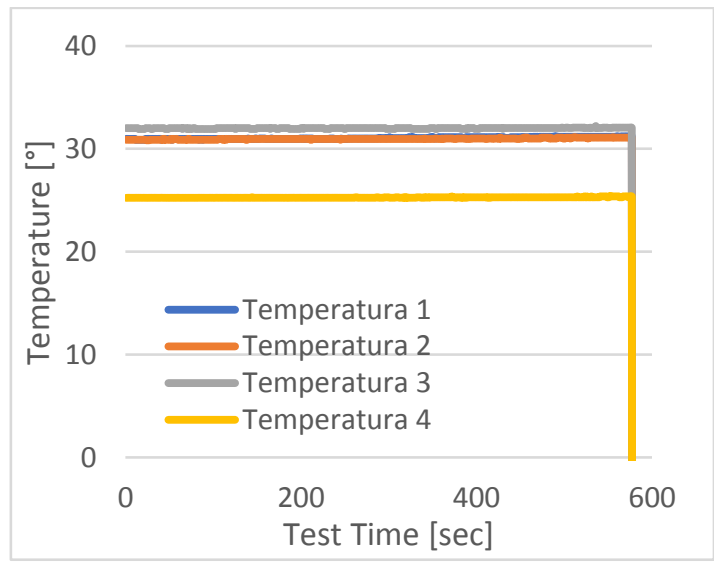

Fig. 17: Temperatures

\subsection{Torque measurement}


The electronic torque measurement developed through a strain gauges bridge presented good results. Fig. 18 shows the result of the static calibration of this system performed by a manual lift and an analogic force dynamometer. Measurements realized on other on-road test conditions show a very good result of this system and could confirm the relationship from electromagnetic braking current, see Fig. 19.

A previous static calibration of the torque performed with a manual lift and an analogic dynamometer indicated a value of $0,210 \mathrm{mV} / \mathrm{V}$ for a force of $5000 \mathrm{~N}$ and a lever of $0,2 \mathrm{~m}$, resulting in a torque of $1.000 \mathrm{Nm}$. The EMB torque by a current of 5,0 A corresponds to $4,88 \mathrm{mV} / \mathrm{V}$.

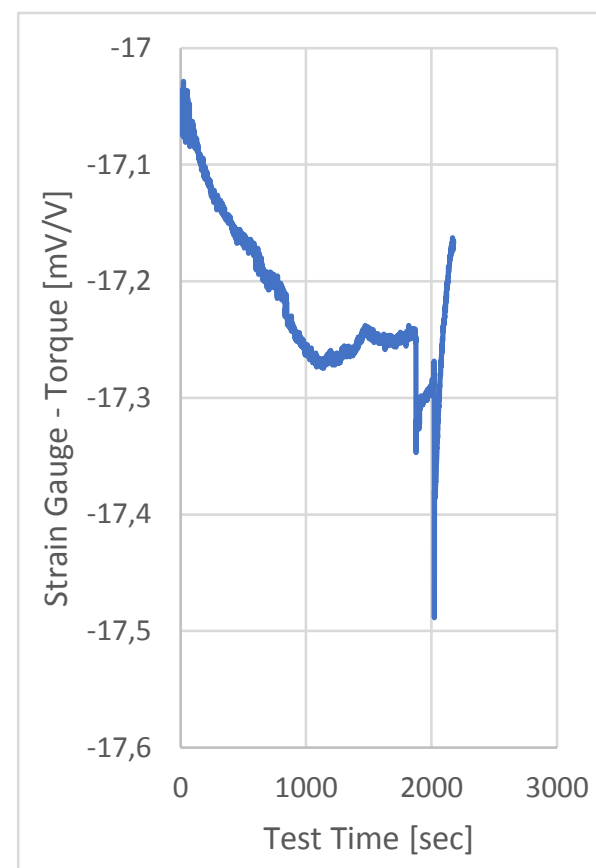

Fig. 18: Static calibration of torque. The values between 1520 and 1870 sec were considered.
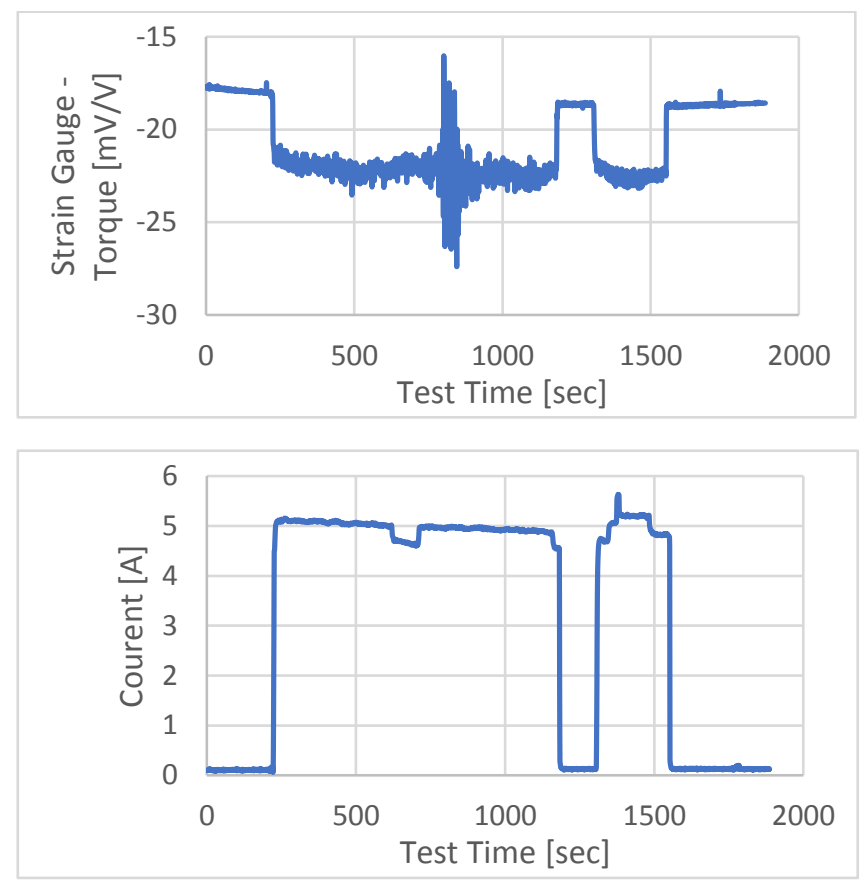

Fig. 19: Relation between torque and electromagnetic brake current during the on road test (Short stop to check instruments between 1185 and $1302 \mathrm{sec}$ ).

\subsection{Consumption electronic measurement}

It was proposed to measure the fuel consumption by measuring the fuel column in an auxiliary tank. This fuel level (fuel column) was calibrated in function of the fuel volume in the auxiliary tank. The electronic consumption level was measured by the strain gage sensor and calibrated in function of the fuel level column, the fuel volume and the fuel mass in the auxiliary tank. This static calibration was possible as shown in Fig. 20 although the tendency for vibration/oscillation of the auxiliary tank suspension. Fig. 21. Consumption measurement at $20 \mathrm{~km} / \mathrm{h}$. At standstill, it is possible to measure the fuel level

The measurement of the consumption should be done presently on standstill vehicles. In future, the steel sheet suspension of the auxiliary tank (with the strain gauges) could be reinforced and /or the electronic signal could be filtered for higher oscillation signals. 


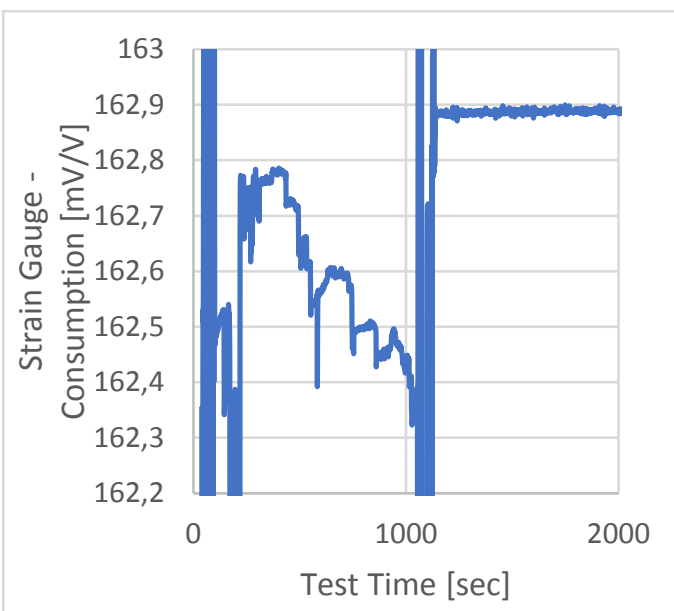

Fig. 20: Consumption calibration at standstill. The high oscillations were human produced to check the stability of the auxiliary tank. The central segment corresponds to 6 liters of fuel.

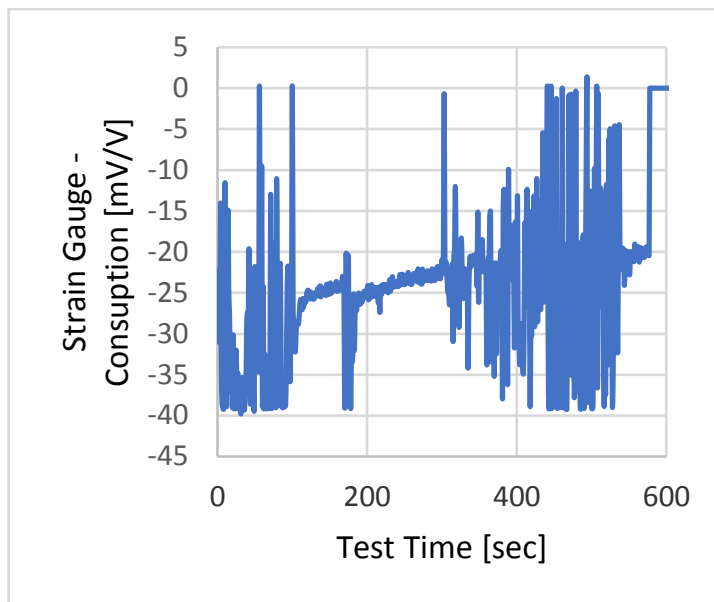

Fig. 21: Consumption measurement at $20 \mathrm{~km} / \mathrm{h}$. At standstill, it is possible to measure the fuel level.

Measurements with a fuel level capacitive sensor in the independent auxiliary fuel tank (8 liters) are ongoing. Future measurements at higher constant speeds and variable speeds up to $90 \mathrm{~km} / \mathrm{h}$ are planned.

\section{SUMARY}

1. Tests performed with the Towing Trailer Prototype show a good possibility to perform controlled, reproducible and forced uphill simulations for fuel consumption measurements.

2. Torque measurements and controls were possible by using the developed strain gauge sensor on the locked electromagnetic brake axis.

3. On road fuel consumption measurements on plain road and by constant speed at 20 $\mathrm{km} / \mathrm{h}$ performed with the independent auxiliary fuel tank showed a good performance for short test distances.

4. The used independent auxiliary fuel tank (8 liters) is too small to perform consumption longer distance measurements.

5. Measurement of the fuel level and the fuel consumption with the independent auxiliary tank by weighting the mass through the strain gauge system shows a possibility of evaluations in short distances. Oscillations must be reduced or suppressed.

\section{CONCLUSIONS}

- The authors, based on the tests, considered that the use of a towing trailer and semitrailer will rise in importance in fuel consumption and emission tests during future developments of commercial vehicles, although references in literature on that matter were not found.

- On-road tests in varied slopes and speeds performed with the auxiliary fuel tank connected with the truck tank and rigidly fixed on the truck chassis will allow fuel consumption measurements for longer distances. 
- Development of measurement of fuel level by a capacitive sensor is ongoing and the tests should be completed in different speeds and electromagnetic brake conditions.

- In future tests of on-road fuel measurements with towing trailer, should be considered the use of devices with higher precision like the ones using CAN or fuel mass flow.

- In future, real driving test conditions with the Towing Trailer Prototype can be extended to emission evaluations.

- Tests should be continued with participation of commercial vehicles and systems manufacturers, to introduce those innovative procedures in Brazil. Support of FAPESP and other government institutions will be very important.

\section{REFERENCES}

[1] France 24, International News $24 / 7$ "From Rio to Paris, a history of climate change summits", International News 24/7 http://www.france24.com/en/20151130-timeline-climate-change-negotiations-kyoto-copenhagencop21

[2] Meyer, Alden, "The difference between 2005 and 2017 is that climate change is now a geopolitical issue of the first order. National Geographic, Union of Concerned Scientists

http://news.nationalgeographic.com/2015/11/151130-paris-talks-climate-co2-kyoto-warming-arctic-antarcticachina-india/.

[3] Girardi, G. http://sustentabilidade.estadao.com.br/blogs/ambiente-se/china-e-estados-unidos-ratificam-oacordo-de-paris/ "China e Estados Unidos ratificam o Acordo de Paris" O Estado de São Paulo 03 September 2016, http://sustentabilidade.estadao.com.br/blogs/ambiente-se/china-e-estados-unidos-ratificam-o-acordo-deparis/ "China e Estados Unidos ratificam o Acordo de Paris". 2016

[4] WHO - UNO World Health Organization, "Global Urban Ambient Air Pollution Database (update 2016)", http://www.who.int/phe/health_topics/outdoorair/databases/cities/en/

[5] PROCONVE: PROGRAMA DE CONTROLE DE POLUIÇÃO DO AR POR VEÍCULOS

AUTOMOTORES, http://www.mma.gov.br/estruturas/163/_arquivos/proconve_163.pdf.

[6] AEA Symposium 2016, 05 and 06 September 2016.

http://www.conpet.gov.br/portal/conpet/pt_br/conteudo-gerais/programa-brasileiro-de-etiquetagem-1.shtml

[7] INMETRO “Portaria n. ${ }^{\circ} 544$ ” - MINISTÉRIO DO DESENVOLVIMENTO, INDÚSTRIA E COMÉRCIO

XTERIOR INSTITUTO NACIONAL DE METROLOGIA, QUALIDADE E TECNOLOGIA -

"PROGRAMA BRASILEIRO DE ETIQUETAGEM PBE"

http://www.inmetro.gov.br/legislacao/rtac/pdf/RTAC001918.pdf Port 544_2012_Def_RAC_PneusNovos_rev04 - Retif pela Port 251_2016.

[8] CONPET - Projeto Nacional da Racionalização do Uso de Derivados de Petróleo e do Gas Natural, "Programa Brasileiro de Etiquetagem",

http://www.conpet.gov.br/portal/conpet/pt_br/conteudo-gerais/programa-brasileiro-de-etiquetagem-1.shtml.

[9] Borges, Marcos, "Programa Brasileiro de Etiquetagem Veicular" (PBEV)

http://www.inmetro.gov.br/consumidor/pbe/veiculos_leves_2015.pd

[10] INMETRO, INSTITUTO NACIONAL DE METROLOGIA,

QUALIDADE E TECNOLOGIA, PROGRAMA BRASILEIRO DE ETIQUETAGEM PBE.

"Tabelas de Consumo/Eficiência Energética Veículos Automotores Leves", 24/11/2015

http://www.inmetro.gov.br/consumidor/pbe/veiculos_leves_2015.pdf

[11] MIDIC - Ministério da Indústria , Comercio Exterior e Serviços,, “Lançamento do Programa Rota 2030 Mobilidade e Logística", http://www.mdic.gov.br/noticias/2447-ministro-marcos-pereira-lanca-rota-2030mobilidade-e-logistica, april, 18th, 2017.

[12] InovarAuto Program, http://www.mdic.gov.br/competitividade-industrial/principais-acoes-dedesenvolvimento-industrial/brasil-produtivo/acordos-internacionais-3,

[13] Fabio Ferreira, "Conciliando Melhorias de Emissões e Consumo Veicular no mercado local" no Simpósio de Eficiência energética, emissões e combustíveis" in da AEA em 23 de maio de 2016.

[14] Rehder, H., "Folder com histórico e características do Reboque de Arrasto", May 2017

[15] Rehder, H., "Testes on road de veículos comerciais com reboque de arrasto inovador provido de freio eletromagnético", paper e paper in SIMEA 2012 - Simpósio Internacional de Engenharia Automotiva promovido pela AEA - Associação Brasileira de Engenharia Automotiva, 9th Setember 2012.

[16] Rehder, H "Avaliação Dinâmica de um reboque de arrasto inovador com freio eletromagnético em testes on road de caminhões" in SAE Symposium 2013 of Vehicle Dynamics, Sorocaba, São Paulo, Brazil.

[17] Rehder,H. and Rehder,G.P," "ON-ROAD COOLING SIMULATION TESTS OF COMMERCIAL VEHICLES PERFORMED BY A TRAILER WITH ELETROMAGNETIC BRAKES”, in AEA SIMEA 2015. [18] Rehder,H. and Rehder,G.P. "Accelerated Durability Tests of Commercial Vehicles Powertrains Performed on Road by a Towing Trailer with an Electromagnetic Brake" presentation and paper in SAE 2015 
[19] Rehder, H., "Reboque ou semirreboque de arrasto com freio eletromagnético para testes de veículos na Estrada”. Request for Patent 0002221164838910 to INPI- Instituto Brasileiro de Propriedade Intelectual,

Brazilian Institute of Intellectual Property, published in Revista da Propriedade Industrial (RPI), Number 2213

on July 2013, published in EPO - European Patent Office (http://worldwide.espacenet.com), CPC Y02T10/7241 and IPC B60L7/00, accessed May 2015.

[20] Rehder, H., "Testes de caminhões leves até semipesados com um reboque de arrasto inovador com freio eletromagnético para simulações on road de aclives", Projeto PIPE I from FAPESP.

[21] DETRAN - Departamento Transito de SP "Certificado de Registro de Veículo", trailer registered for 20 tons, as CARRETA/REBOQUE/MEC. OPERACONAL, CTU 29241/SP by the State Traffic Authority on Jan.3rd 2011, last License 2017.

[22] Quora "How can I measure fuel level in vehicle, capacitive \& ultrasonic sensor, which one is better? https://www.quora.com/How-can-I-measure-fuel-level-in-vehicle-capacitive-ultrasonic-sensor-which-one-isbetter

[23] Zaccai, E; Rodrigues, E.B. and Moreno,A.M , "INFLUÊNCIA DOS PNEUS NO CONSUMO DE COMBUSTÍVEL DE VEÍCULOS PESADOS”. setember 2015 vol. 2 num. 1 - XXIII Simpósio Internacional de Engenharia Automotiva, - Open Access. DOI: 10.5151/engpro-simea2015-PAP188

[24] Modern Drive Technology, http://moderndrive.de/produkte/eco-training/www.moderndrive.de

[25] AVL, "On board fuel consume measurement". https://www.avl.com/-/avl-m-o-v-e-pm-pems-portable-sootand-pm-measurement-device-on-board-a-vehicle, assessed Mai 2017.

[26] Standard SAE J1321 201202, revised 20-12-06," Fuel Consumption Test Procedure Type II".

[27] Mahle,"Eine Neue Dimension in Forschung und Entwicklung",

http://media.mahle.com/mc/epaper?guid=147389025ef44506\&lang=de, accessed May, 2015. 


\section{Appendix 1 - Page 1: Tower Trailer Prototype. Folder August 2017 (Extract)}

Background: Since the Decade of 70's, on road tests to evaluate the thermal performance of cooling systems of commercial vehicles, are very complicated, several trucks are required to perform them. Stationary installations with chassis dynamometers and big fans were not feasible in Brazil due to the high costs.

Trailer Mounting: In 2011 studies were initiated for a tower trailer to simulate uphill tests. The Prototype was mounted using a second-hand sugar cane trailer. It was installed an electromagnetic brake with electrical supply and control systems, gearbox, clutch, rear axle with differential and drive shaft system for transmission of the braking torque.

Technical Characteristics: The prototype of the trailer has been approved in 2012 by the Brazilian Traffic Authority CONTRAN as Operational Mechanism for 20 tons. It's $2.6 \mathrm{~m}$ wide, $8.2 \mathrm{~m}$ long and a current weight of $12 \mathrm{t}$, with $4 \mathrm{t}$ of ballast (gravel) in the bucket installed in the back. It has 2 axles with 811.00 R22 tires and can also drag another vehicle.

Patent registration: Required in May/2011 to INPI - Brazilian Institute for Intellectual Propriety, was published in the of Industrial Property Magazine (RPI) No. 2213 of 07/2013 and still under examination.

Tests on the road: The Towing Trailer shows easy coupling to tractor truck, great application flexibility, the convoy has a good maneuverability and safety, even on not pavemented roads. The Trailer also has a high mechanical resistance, since its components are normally used in the heavy work in sugar cane crops. Weight limits of trucks for testing on public roads are dictated by legislation. For buses and agricultural tractor testing's, the traction rod can be lowered.
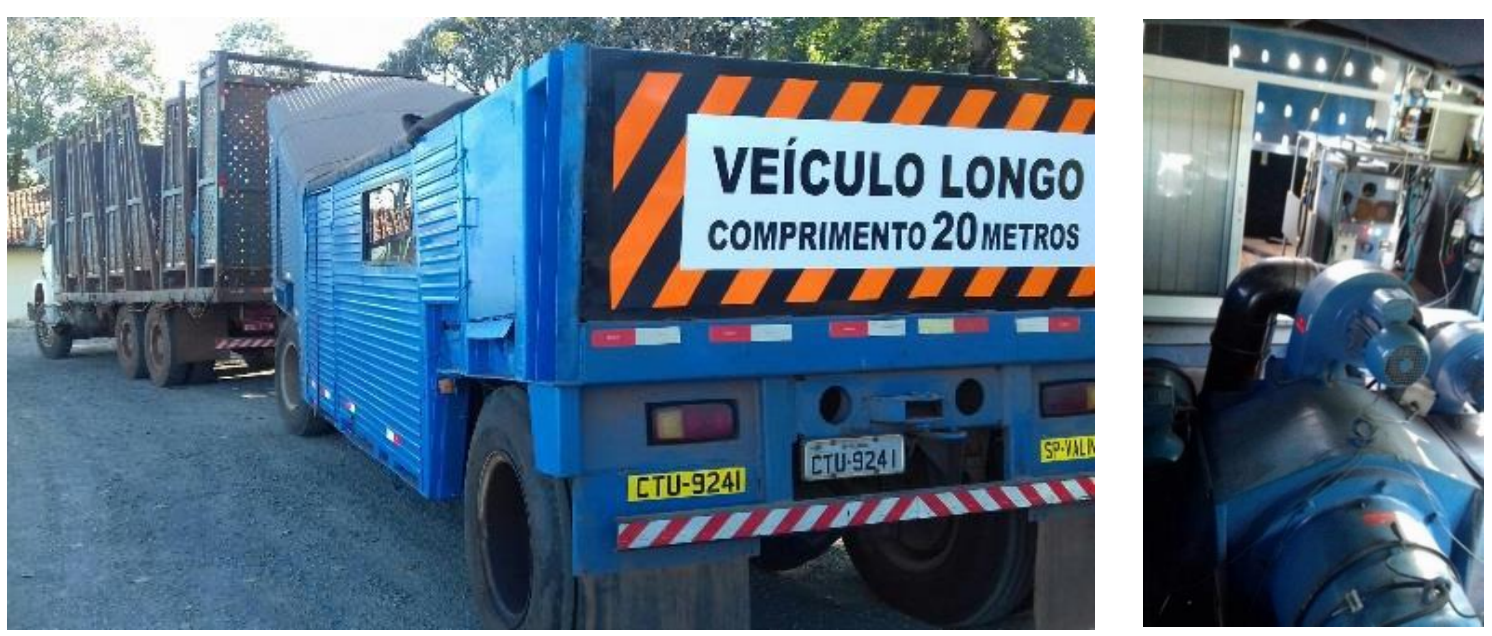

Top: Convoy composed by the Towing Trailer and a 6x4 Truck. Left view.

Right: Inside Towing Trailer, electromagnetic brake and in background the electro electronic cab 


\section{Appendix 1 - Page 2: Tower Trailer Prototype. Folder August 2017 (Extract)}

Testing limits: The initial braking power was increased by optimizing the layout, the electromagnetic brake cooling and power supply system. Cooling tests are possible (usually at 20 $\mathrm{km} / \mathrm{h}$ ) for vehicles up to $250 \mathrm{HP}$. Also, possible on road tests up to $90 \mathrm{~km} / \mathrm{h}$ and higher potencies, in accelerated durability tests of powertrain, tires and other components as well as fuel consumption tests.

Electro Electronics: A control cabin on the front of the trailer brings together all the electric and electronic measurements and system controls and sends and receives Wi-Fi the information to a laptop placed in the cab of the tractor truck. The forces between tractor truck and trailer are measured by a specially developed sensor with strain gauges and sent also the signals to the laptop. New system based on strain-gauges was also developed for measuring the electromagnetic braking torque. The command and control during testing can be performed in the cab of the tractor vehicle and the Wi-Fi data, registered as showed in the figures below. Data can be logged on datasheets and allow the elaboration of graphics.

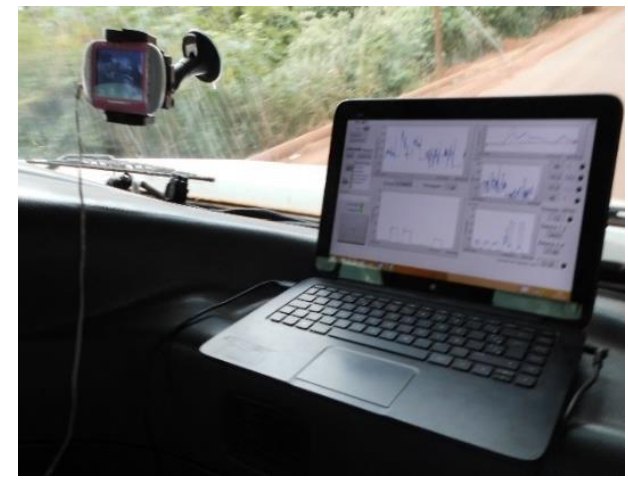

Laptop in the truck cabin during on road test.

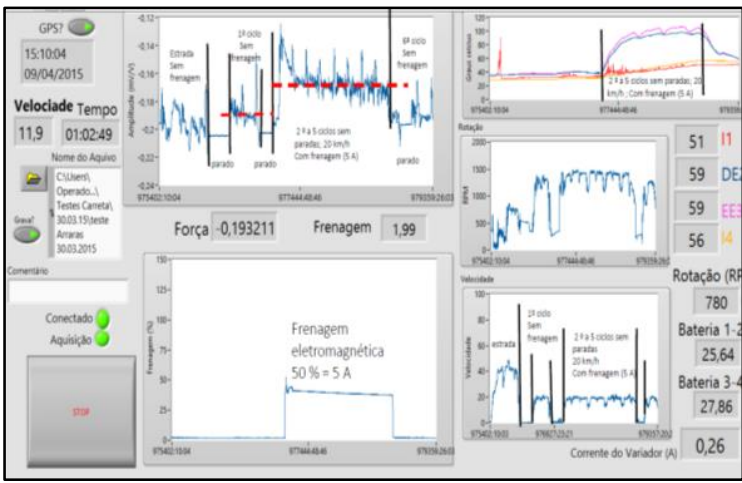

Laptop screen during test (exemple).

Advantages: The towing trailer can be monitored in the cab of the tractor by the technician who performs the measurements and can also easily adjust the braking power. There is no need for other trucks and drivers, reducing the costs of the tests. Easy maneuverability, can travel on public roads, observed the weight legislation limits.

Developments: The developments had initially a partial support of FAPESP, through the PIPE Project 2012/50992-7. Testing and incremental developments in commands and other items are in progress, including fuel consumption, using a capacitive sensor for measurement of the fuel level. Development of a towing semi-trailer for testing trucks with higher power is planned as well consumption measurements with different methodologies. 
Appendix 2: AN EXEMPLE OF A DATA SHEET 17 SEC. (SPEED NOT REGISTRED)

\begin{tabular}{|c|c|c|c|c|c|c|c|c|c|c|c|c|c|c|c|c|}
\hline Tempo & Torque & Força & Temperatura 1 & Temperatura 2 & Temperatura 3 & Temperatura 4 & Corrente & Velocidade & Porcentagem & Rotação 1 & Latitude & Longitude & Bateria 1 & Bateria 2 & Data e Hora & Consumo \\
\hline 171,5733 & $-17,9987$ & 0,898793 & 43,96381 & 39,54265 & 37,1552 & 61,96515 & 0,181404 & 0,3704 & 0,181404 & 0,87008 & $-22,3756$ & $-47,2518$ & 18,53899 & 25,07507 & $18: 26: 58$ & $-497,761$ \\
\hline 172,5735 & $-17,9922$ & 0,901098 & 43,56984 & 39,12718 & 36,73299 & 61,52298 & 0,174778 & 0,5556 & 0,174778 & 0,870451 & $-22,3756$ & $-47,2518$ & 18,34386 & 25,09694 & 18:26:59 & $-497,756$ \\
\hline 173,5742 & $-17,994$ & 0,901551 & 44,57241 & 40,09663 & 37,71898 & 62,55713 & 0,094748 & 0,926 & 0,094748 & 0,885985 & $-22,3756$ & $-47,2518$ & 18,89402 & 25,10961 & $18: 27: 00$ & $-497,784$ \\
\hline 174,5734 & $-17,9848$ & 0,900986 & 44,18188 & 39,71924 & 37,33654 & 62,15556 & 0,136981 & 1,2964 & 0,136981 & 0,859453 & $-22,3756$ & $-47,2518$ & 18,73327 & 25,08341 & 18:27:01 & $-497,769$ \\
\hline 175,574 & $-17,9842$ & 0,894211 & 43,52415 & 39,17302 & 36,69411 & 61,47987 & 0,171843 & 1,852 & 0,171843 & 0,871727 & $-22,3756$ & $-47,2518$ & 18,41801 & 25,07859 & $18: 27: 02$ & $-497,533$ \\
\hline 176,5734 & $-17,988$ & 0,888956 & 43,35113 & 39,00535 & 36,52574 & 61,30245 & 0,160334 & 1,852 & 0,160334 & 0,875525 & $-22,3756$ & $-47,2518$ & 18,29698 & 25,08169 & $18: 27: 03$ & $-497,693$ \\
\hline 177,5741 & $-17,9948$ & 0,901219 & 44,29946 & 39,95292 & 37,48626 & 62,30959 & 0,129188 & 1,4816 & 0,129188 & 0,858074 & $-22,3756$ & $-47,2518$ & 18,4194 & 25,11021 & 18:27:04 & $-497,983$ \\
\hline 178,5745 & $-17,9756$ & 0,895907 & 43,83677 & 39,50778 & 37,03166 & 61,83264 & 0,168649 & 1,2964 & 0,168649 & 0,897648 & $-22,3756$ & $-47,2518$ & 18,81408 & 25,09302 & $18: 27: 05$ & $-498,119$ \\
\hline 179,5736 & $-17,9855$ & 0,902714 & 43,70143 & 39,28104 & 36,89538 & 61,69075 & 0,18286 & 1,4816 & 0,18286 & 0,841829 & $-22,3756$ & $-47,2518$ & 18,71208 & 25,1001 & $18: 27: 06$ & $-497,881$ \\
\hline 180,5734 & $-17,988$ & 0,895658 & 43,18509 & 38,78666 & 36,43119 & 61,16237 & 0,141912 & 1,4816 & 0,141912 & 0,826578 & $-22,3756$ & $-47,2518$ & 18,26538 & 25,10587 & $18: 27: 07$ & $-497,737$ \\
\hline 181,5744 & $-17,9976$ & 0,899224 & 44,21889 & 39,87245 & 37,44401 & 62,22533 & 0,12752 & 1,1112 & 0,12752 & 0,861407 & $-22,3756$ & $-47,2518$ & 19,0132 & 25,09017 & $18: 27: 08$ & $-497,954$ \\
\hline 182,5741 & $-17,9801$ & 0,898464 & 43,98342 & 39,6487 & 37,21452 & 61,98505 & 0,153766 & 0,7408 & 0,153766 & 0,836847 & $-22,3756$ & $-47,2518$ & 18,48213 & 25,0877 & $18: 27: 09$ & $-497,896$ \\
\hline 183,5739 & $-17,9896$ & 0,904956 & 43,87379 & 39,54295 & 37,10515 & 61,87004 & 0,169802 & 0,7408 & 0,169802 & 0,85584 & $-22,3756$ & $-47,2518$ & 18,40288 & 25,08284 & $18: 27: 10$ & $-497,971$ \\
\hline 184,5734 & $-17,9918$ & 0,896813 & 43,7449 & 39,41663 & 36,97898 & 61,73567 & 0,162597 & 0,7408 & 0,162597 & 0,861759 & $-22,3756$ & $-47,2518$ & 18,35445 & 25,07499 & $18: 27: 11$ & $-497,767$ \\
\hline 185,5749 & $-18,0051$ & 0,90552 & 44,49873 & 40,18083 & 37,7176 & 62,51468 & 0,085627 & 1,2964 & 0,085627 & 0,852643 & $-22,3756$ & $-47,2518$ & 19,06114 & 25,07473 & $18: 27: 12$ & $-497,901$ \\
\hline 186,5734 & $-17,9946$ & 0,893191 & 43,43255 & 39,15092 & 36,67155 & 61,41623 & 0,166218 & 1,1112 & 0,166218 & 0,850462 & $-22,3756$ & $-47,2518$ & 18,29979 & 25,09207 & $18: 27: 13$ & $-497,828$ \\
\hline 187,5735 & $-17,9795$ & 0,896743 & 44,00406 & 39,70446 & 37,2357 & 62,00437 & 0,16354 & 0,926 & 0,16354 & 0,858585 & $-22,3756$ & $-47,2518$ & 18,48525 & 25,09415 & $18: 27: 14$ & $-497,986$ \\
\hline 188,5734 & $-17,9915$ & 0,88685 & 43,25308 & 38,94756 & 36,46335 & 61,1931 & 0,134528 & 1,1112 & 0,134528 & 0,871279 & $-22,3756$ & $-47,2518$ & 18,24802 & 25,10093 & $18: 27: 15$ & $-497,867$ \\
\hline 189,5735 & $-18,006$ & 0,896077 & 43,70301 & 39,49843 & 36,9858 & 61,78263 & 0,188224 & 1,2964 & 0,188224 & 0,874464 & $-22,3756$ & $-47,2518$ & 18,35338 & 25,09415 & $18: 27: 16$ & $-497,921$ \\
\hline 190,5734 & $-17,9925$ & 0,894202 & 43,10888 & 38,92707 & 36,40732 & 61,17485 & 0,138256 & 1,4816 & 0,138256 & 0,863997 & $-22,3756$ & $-47,2518$ & 18,20039 & 25,10556 & $18: 27: 17$ & $-497,793$ \\
\hline 191,5734 & $-17,9868$ & 0,89797 & 43,73264 & 39,52774 & 37,01621 & 61,81639 & 0,171549 & 1,2964 & 0,171549 & 0,875656 & $-22,3756$ & $-47,2518$ & 18,39196 & 25,10688 & 18:27:18 & $-498,83$ \\
\hline 192,5754 & $-17,9812$ & 0,90003 & 43,93842 & 39,73307 & 37,2208 & 62,02952 & 0,152403 & 1,1112 & 0,152403 & 0,852726 & $-22,3756$ & $-47,2518$ & 18,51525 & 25,08304 & $18: 27: 19$ & $-497,848$ \\
\hline 193,5735 & $-17,9933$ & 0,90727 & 44,45469 & 40,22659 & 37,72471 & 62,56036 & 0,083919 & 1,2964 & 0,083919 & 0,857187 & $-22,3755$ & $-47,2517$ & 18,99249 & 25,09188 & $18: 27: 20$ & $-498,164$ \\
\hline
\end{tabular}

